\title{
Perception and Attitude of Public about Hand Sanitizers and Disinfectants in Saudi Arabia
}

\begin{abstract}
Yousef Ahmed Alomi* iD, BSc. Pharm, MSc. Clin Pharm, BCPS, BCNSP, DiBA, CDE, Critical Care Clinical Pharmacists, TPN Clinical Pharmacist, Freelancer Business Planner, Content Editor and Data Analyst, Riyadh, Saudi Arabia.
\end{abstract}

Basmah Sulimain AlHamdan, Senior Quality Specialist, King Fahad Medical City, Riyadh, SAUDI ARABIA.

Sahar Obaid Alosaimi,

College of Pharmacy, Taif University, Taif, SAUDI ARABIA.

Deema Abdullah Altuwayhir, College of Dentistry, Hail University, Hail, SAUDI ARABIA.

Aseel Hamed Alzaidi,

College of Pharmacy, Tail University, Tail, SAUDI ARABIA.

\section{Correspondence:}

Dr. Yousef Ahmed Alomi, BSc. Pharm, MSC Clin Pharm, BCPS, BCNSP, DiBA, CDE, Critical Care Clinical Pharmacists, TPN Clinical Pharmacist, Freelancer Business Planner, Content Editor and Data Analyst, Riyadh 11392, Riyadh, Saudi Arabia.

Phone no: +966504417712 E-mail: yalomi@gmail.com
Received: 03-01-2021;

Accepted: 25-03-2021.

Copyright: (c) the author(s),publisher and licensee Pharmacology, Toxicology and Biomedical Reports. This is an open-access article distributed under the terms of the Creative Commons Attribution NonCommercial License, which permits unrestricted non-commercial use, distribution, and reproduction in any medium, provided the original work is properly cited.

This is an open access article distributed under the terms of the Creative Commons AttributionNonCommercial-ShareAlike 4.0 License

Access this article online

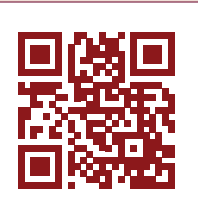

www.ptbreports.org

DOI:

10.5530/PTB.2021.7.18

\begin{abstract}
Objectives: The public had malpractice and attitudes toward hand sanitizer and disinfectants during epidemic and pandemic situations. Even though there is evidence that sanitizers and disinfectants are efficacious and prevent disease transmission, the public's perception and attitude about their efficacy are still controversial. Therefore, in this study, we aimed to investigate the perception and attitude of hand sanitizers and disinfectants in the Kingdom of Saudi Arabia. Design and Setting: A self-administered, structured questionnaire was sent to the public via online mode. The survey collected demographic information and information about perception and attitude about using hand sanitizer or disinfectant during COVID-19. Data were analyzed with the SPSS program. Results: A total of 402 participants responded to the questionnaire. Of them, $32.58 \%$ were from the western region, and $25.76 \%$ were from the central region, with statistically significant differences between different regions $(p=0.000)$. Most of the responders $(90.88 \%)$ were Saudi nationals. In addition, the majority of the responders $(65.17 \%)$ were females, with statistically significant differences between males and females $(p=0.000)$. The average score for attitude was 2.65 . The average score for the perception was obtained for the element "dedicate a specific place in the house to store hand sanitizer or disinfectant" (3.90). The responders accepted the sanitizer of disinfectant information from the health practitioners (3.75). The average score of perception was 3.18. The part with most perception by the patient was "the efficacy and safety of sanitizer and disinfectant is the best factor to get them" (4.01), and "there is a big difference between sanitizer and disinfectant in effectiveness and safety" (3.75). Conclusion: The public's perception of sanitizers and disinfectants was inadequate in the Kingdom of Saudi Arabia. The public had the perception of knowledge of sanitizers and disinfectants, appropriate storage conditions, non-usage of herbal medications, and use of sanitizers and disinfectants. However, they had a wrong perception of the benefits of sanitizer and disinfectant-related problems. Therefore, public awareness about sanitizer and disinfectants should be improved in the Kingdom of Saudi Arabia.

Key words: Public, Perception, Sanitizer, Disinfectants, Saudi Arabia.
\end{abstract}

\section{INTRODUCTION}

Sanitizers and disinfectants have become highly essential during the COVID-19 pandemic. $^{1-4}$ Various national and international organizations have recommended the use of sanitizers and disinfectants during this period. ${ }^{3-5}$ Although these products have multiple benefits, they can show adverse drug reactions; ${ }^{1-4}$ for example, some sanitizers can cause allergic reactions. ${ }^{1-4,6}$ Furthermore, some disinfectants can induce asthma in individuals who have lung problems. ${ }^{1-4,6}$ That has caused some people to think about sanitizers and disinfectants negatively, and they will not use them in the future, even during a pandemic or emergency situation. In addition, some other individuals experience barriers that prevent them from using sanitizers and disinfectants. Some previous studies have discussed the perception of the public about infection control measures, including sanitizers and disinfectants during COVID-19. ${ }^{7-14}$ However, most of those studies have been conducted during the pre-COVID-19 period. Furthermore, previous research has discussed the practice of people in using sanitizers and disinfectants. ${ }^{14}$ To the best of our knowledge, there are no studies conducted on the perception and attitude of people about sanitizer and disinfectants in Saudi Arabia or the Middle Eastern countries.
Therefore, in this study, we assessed the public perception of sanitizer and disinfectants in Saudi Arabia.

\section{MATERIALS AND METHODS}

This quantitative cross-sectional survey was conducted in Saudi Arabia for four months through a self-administered electronic survey questionnaire. The study included all Saudi Arabian citizens. Any incomplete responses or responses from outside Saudi Arabia were excluded. An online self-developed questionnaire was distributed to the public across Saudi Arabia. The survey collected demographic data, such as location, gender, material status, age, qualification, occupational status, and monthly income. The second part collected information about people's attitudes toward hand sanitizer and disinfectant use and their perception during COVID-19. We used a 5-point Likert response scale system to obtain responses. The survey was distributed to a convenient sample of public responders via social media such as WhatsApp and Telegram and via face-to-face contact. A reminder message was sent once every 1-2 weeks. All completed surveys from Saudi nationals were included in the final analysis. According to the 
previous literature, the sample was calculated with unlimited population size, a population percentage of $50 \%$, a confidence level of $95 \%$, a $\mathrm{z}$ score of 1.96 , a margin of error of $5 \%$, and a drop-out rate of $5 \%$. Consequently, the sample size was calculated as 399 with the power of study of $80 \% \cdot{ }^{15-17}$ The response rate required for the estimated sample size was at least $60-70 \% .^{17,18}$ Expert reviewers and pilot testing validated the survey data. The data's reliability was tested by McDonald's $\omega$, Cronbach's $\alpha$, Guttman's $\lambda 2$, and Guttman's $\lambda 6$. The data were collected through the Survey Monkey system and analyzed using Statistical Package of Social Sciences (SPSS), Jeffery's Amazing Statistics Program (JASP), and Microsoft Excel (version 16) software. We performed descriptive and frequency analysis, the goodness of fit analysis, correlation analysis, and inferential analysis between independent variables. The STROBE (Strengthening the reporting of observational studies in epidemiology statement: guidelines for reporting observational studies) guided the reporting of this study. ${ }^{19-21}$

\section{RESULTS}

A total of 402 participants responded to the questionnaire. Only participants who completed all the sections in the questionnaire were included in the analysis. The scores for reliability tests were as follows: McDonald's $\omega$ was (0.903), Cronbach's $\alpha$ was (0.893), Guttman's $\lambda 2$ was (0.906), Guttman's $\lambda 6$ was (0.925), Greatest Lower Bound was (0.962). Socio-demographics of the responders and analysis of the questionnaire are shown below. Out of 402 participants, $32.58 \%$ were from the western region, $25.76 \%$ were from the central region, with statistically significant differences between all regions $(p<0.001)$. Most of the responders were Saudi Nationals $(90.88 \%)$. Furthermore, the majority of the responders were females $(65.17 \%)$, with statistically significant differences between both genders $(p<0.001)$. Based on the age of the responders, there were five sub-categories. The majority of the responders belonged to the age group of $18-29$ years $(50.25 \%)$, with statistically significant differences between all age groups $(p<0.001)$. Table 1 shows all socio-demographic

\begin{tabular}{|c|c|c|c|}
\hline Nationality & Response Count & Response Percent & $p$-value \\
\hline Central area & 102 & $25.76 \%$ & \multirow[t]{5}{*}{0.000} \\
\hline North area & 54 & $13.64 \%$ & \\
\hline South area & 76 & $19.19 \%$ & \\
\hline East area & 35 & $8.84 \%$ & \\
\hline West area & 129 & $32.58 \%$ & \\
\hline Answered question & 396 & & \\
\hline Skipped question & 6 & & \\
\hline Nationality & Response Count & Response Percent & \\
\hline Saudi & 339 & $90.88 \%$ & \multirow[t]{2}{*}{0.000} \\
\hline Non-Saudi & 34 & $9.12 \%$ & \\
\hline Answered question & 373 & & \\
\hline Skipped question & 29 & & \\
\hline Gender & Response Count & Response Percent & \\
\hline Male & 140 & $80.45 \%$ & \multirow[t]{2}{*}{0.000} \\
\hline Female & 262 & $19.55 \%$ & \\
\hline Answered question & 402 & & \\
\hline Skipped question & 0 & & \\
\hline Age & Response Count & Response Percent & \\
\hline$<18$ & 35 & $8.71 \%$ & \multirow[t]{5}{*}{0.000} \\
\hline $18-29$ & 202 & $50.25 \%$ & \\
\hline $30-44$ & 110 & $27.36 \%$ & \\
\hline $45-60$ & 41 & $10.20 \%$ & \\
\hline$>60$ & 14 & $3.48 \%$ & \\
\hline Answered question & 402 & & \\
\hline Skipped question & 0 & & \\
\hline
\end{tabular}

Table 2: Social and professional information of responders.

\begin{tabular}{|c|c|c|c|}
\hline Responder Qualifications & $\begin{array}{l}\text { Response } \\
\text { Count }\end{array}$ & $\begin{array}{l}\text { Response } \\
\text { Percent }\end{array}$ & $p$-value \\
\hline Doctorate & 8 & $1.99 \%$ & \multirow[t]{8}{*}{0.000} \\
\hline Master's degree & 37 & $9.20 \%$ & \\
\hline Bachelor's degree & 264 & $65.67 \%$ & \\
\hline Diploma & 32 & $7.96 \%$ & \\
\hline High school & 48 & $11.94 \%$ & \\
\hline Intermediate School & 10 & $2.49 \%$ & \\
\hline Primary School & 2 & $0.50 \%$ & \\
\hline Not educated & 1 & $0.25 \%$ & \\
\hline Answered question & 402 & & \\
\hline Skipped question & 0 & & \\
\hline Occupational status & $\begin{array}{c}\text { Response } \\
\text { Count }\end{array}$ & $\begin{array}{c}\text { Response } \\
\text { Percent }\end{array}$ & \\
\hline Employee & 140 & $34.91 \%$ & \multirow[t]{4}{*}{0.000} \\
\hline Non-employee & 105 & $26.18 \%$ & \\
\hline Student & 137 & $34.16 \%$ & \\
\hline Retried & 19 & $4.74 \%$ & \\
\hline Answered question & 401 & & \\
\hline Skipped question & 1 & & \\
\hline $\begin{array}{l}\text { Are you a health care practitioner } \\
\text { (Medical Doctor- Dentist- } \\
\text { Pharmacist- Nurse- Others? }\end{array}$ & $\begin{array}{l}\text { Response } \\
\text { Count }\end{array}$ & $\begin{array}{l}\text { Response } \\
\text { Percent }\end{array}$ & \\
\hline Yes & 148 & $36.82 \%$ & \multirow[t]{2}{*}{0.000} \\
\hline No & 254 & $63.18 \%$ & \\
\hline Answered question & 402 & & \\
\hline Skipped question & $\mathbf{0}$ & & \\
\hline $\begin{array}{l}\text { If you are a health care practitioner, } \\
\text { you are a }\end{array}$ & $\begin{array}{c}\text { Response } \\
\text { Count }\end{array}$ & $\begin{array}{c}\text { Response } \\
\text { Percent }\end{array}$ & \\
\hline Physician & 11 & $7.43 \%$ & \multirow[t]{4}{*}{0.000} \\
\hline Dentist & 9 & $6.08 \%$ & \\
\hline Pharmacist & 116 & $78.38 \%$ & \\
\hline Nurse & 4 & $2.70 \%$ & \\
\hline Other (please specify) & 8 & $5.41 \%$ & \\
\hline Answered question & 148 & & \\
\hline Skipped question & 254 & & \\
\hline
\end{tabular}

data. With respect to the education level, the majority of the responders (65.67\%) had a bachelor's degree, followed by employed (34.91\%), students (34.16\%), and non-employees (26.18\%), with statistically significant differences between all levels $(p<0.001)$. Participants were also asked if they were working in the medical field. Only $36.82 \%$ were healthcare practitioners, whereas $78.38 \%$ of these practitioners were pharmacists with statistically significant differences between specialties $(p<0.001)$ (Table 2).

Responders were asked to choose a level of perception among Publics acts toward hand sanitizer and disinfectant during COVID-19. The average score was 2.65. The question that received most of the response was "dedicate a specific place in the house to store hand sanitizer or disinfectant" (3.90), and "to what extent do you accept the sanitizer of disinfectant information provided by health practitioners" (3.75). 
However, the element with the lowest perception was "the poor understanding of hand sanitizer or disinfectant cause the critical care admissions" (1.87). Followed by the elements "the poor knowledge of hand sanitizer or disinfectant causes you to visit the emergency section" (1.89) and "the poor understanding of hand sanitizer or disinfectant causes you to hospital admission" (1.89), with statistically significant differences between responses $(p<0.001)$ (Table 3$)$.

Next, the average score for the "perceptions of public towards using hand sanitizer and disinfectants during COVID-19" was 3.18. Patients responded the most for "the efficacy and safety of sanitizer and disinfectant is the best factor to get them" (4.01), "there is a big difference between sanitizer and disinfectant in effectiveness and safety" (3.75), and "you can find the sanitizer and disinfectant at most places at my house" (3.51). However, the element with the lowest perception was "sanitizer and disinfectant have no significant benefit" (2.40), and "herbal medicines used as sanitizers and disinfectants are much better than regular sanitizer and disinfectants" (2.54). Besides, the statement "there are no side effects for sanitizer and disinfectant" (2.7), with statistically significant differences between responses $(p<0.001)$ (Table 4$)$.

\section{Factors affecting the acts and performances toward the public toward the sanitizer and disinfectant during the COVID-19 pandemic}

Several factors affected the public acts and performances toward hand sanitizer and disinfectant during COVID-19. Using independent samples Kruskal-Wallis test and the Bonferroni correction for multiple tests, we adjusted the significant values. The factors that affected the public's attitude toward hand sanitizer and disinfectants were location, nationality, gender, age, qualification, occupational status, and whether the responder was a healthcare practitioner (e.g., doctor, dentist, pharmacist, and nurse). Most of the factors (e.g., nationality and worksite) did not affect the knowledge of storage, with a non-statistically significant difference $(p>0.05)$. Five locations affected the attitude of the public toward hand sanitizer and disinfectant. The highest score (3.4930) was obtained for the western region, and the lowest score (3.1772) was obtained for the southern region, with a statistically significant difference between all regions $(p=0.003)$. Gender affected the attitude of the public toward hand sanitizer and disinfectants. Females obtained a higher score (3.4102) than males (3.2379), with a statistically significant difference between them $(p=0.025)$. Five different age groups affected the attitude of the public toward hand sanitizer and disinfectant use. The lowest score (2.8841) was obtained for the age group of $<18$ years, with a statistically significant difference between the age groups $(p=0.000)$. Eight different educational levels affected the attitude of the public toward hand sanitizer and disinfectant use. The lowest (3.0523) score was obtained for the responders who completed high school, with a statistically significant difference between all levels $(p=0.004)$. Responders who were healthcare professionals received higher scores (3.4620) than those who were non-healthcare professionals (3.2865), with a statistically significant difference between them $(p=0.000)$.

The relationship between public the public acts and performances toward hand sanitizer and disinfectant during the COVID-19 pandemic and its factors were studied. The multiple regression analysis revealed a weak relationship ( $R=0.247$ with $p=0.003$ ) between the attitude of the public toward hand sanitizer and disinfectant and factors affecting it. According to the results, five out of seven factors showed non-significant differences $(p>0.05)$. However, age and gender explained $15.9 \%$ and $12.9 \%$ of the positive relationship, with a statistically significant $(p=0.004$ and 0.022 , respectively) difference. The bootstrap model confirmed the results. And it was verified by the non-existence of multi-collinearity with the current position factor with Variance Inflation Factor (VIF) of 1.103 and 1.173), respectively, which is less than 3 or $5^{22-24}$ (Table 5).

\section{Factors affecting the attitude of the public toward hand} sanitizer and disinfectant during COVID-19

Several factors affected the perception of the public about the use of hand sanitizer and disinfectants during COVID-19. Using independent samples Kruskal-Wallis test and the Bonferroni correction for multiple tests, we adjusted the significant values. The factors that affected the perception of hand sanitizer and disinfectants during COVID-19 were locations, nationality, gender, age, qualification, occupational status, and whether the responders were healthcare practitioners (e.g., doctor, dentist, pharmacist, and nurse-). However, all these factors mentioned above did not affect the perception significantly $(p>0.05)$.

The relationship between the public's perception towards the usage of hand sanitizer and disinfectants during the COVID-19 and factors. The multiple regression analysis revealed a weak relationship ( $\mathrm{R}=0.153$ with $p=0.315$ ) between the public's perception toward hand sanitizer and disinfectants and factors affecting it. Six out of seven factors showed nonsignificant differences $(p>0.05)$. However, age alone explained a $12.4 \%$ positive relationship with a statistically significant difference $(p=0.027)$. The non-existence of multi-collinearity verified the relationship with the current position factor with VIF of 1.105 , which is less than 3 or $5^{22-24}$ (Table 6).

\section{DISCUSSION}

Over the past two years, the COVID-19 pandemic has created tough and challenging situations worldwide. ${ }^{25,26}$ Various international organizations released medical guidelines and recommendations for the prevention and management. ${ }^{27,5,28}$ Sanitizers and disinfectants were one of the highly recommended measures to be strictly followed for the prevention of the spread of the disease. ${ }^{1-4}$ However, these aforementioned products might have been underused or overused, which could be related to misunderstanding or misconception among the public and patients. ${ }^{29,30}$ Moreover, some malpractice acts of the sanitizer or disinfectant. ${ }^{29,30}$ The assessment of the public's perception about sanitizer and disinfectant use will encourage healthcare organizations to deal with the public during the pandemic. Therefore, this study was conducted to explore the attitudes and perceptions of the people about sanitizers and disinfectants. The self-administered electronic questionnaire was validated with a high-reliability score. It was distributed to various regions, working sites, age groups, occupational status, and whether the responders were healthcare professionals or not. ${ }^{14}$ Therefore, it was reasonable to discover all perceptions through different populations and various types and society levels. The finding showed that public attitude toward the sanitizer and disinfectant was inadequate. People showed a more positive attitude to the storage of the sanitizer and disinfectant in proper places in the houses. The public might put high proprieties for sanitizer and disinfectant to prevent any accidental injury that may have occurred at home and consider them like any regular medication. Thus, they thought that they should prescribe or dispense sanitizer and disinfectant through healthcare providers. The responders believed that poor knowledge and understanding of sanitizer and disinfectants might lead them to emergency or hospital and critical care admission. They thought that some of the sanitizers and disinfectants might contain methanol, and if mistakenly ingested, might lead them to an emergency.

Moreover, asthma patients might be allergic to certain chemicals used in disinfectants, which might cause an emergency situation. The study results showed the public's inadequate perception of the use of sanitizers and disinfectants. Some responders had a positive, whereas others had a negative perception. The elements which say "people considered the efficacy and safety of the essential factor in choosing the sanitizer 


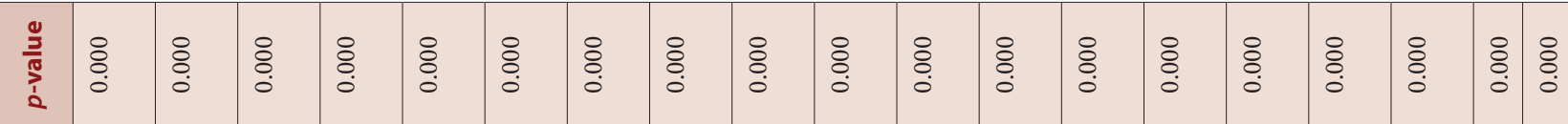

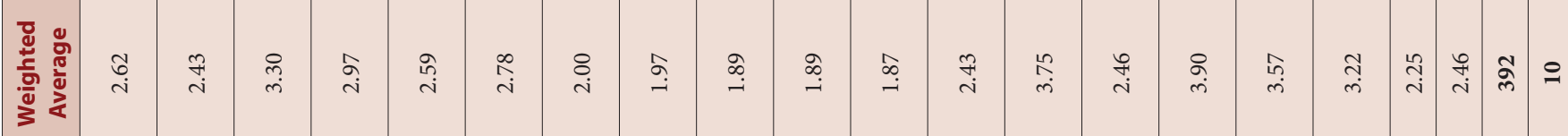

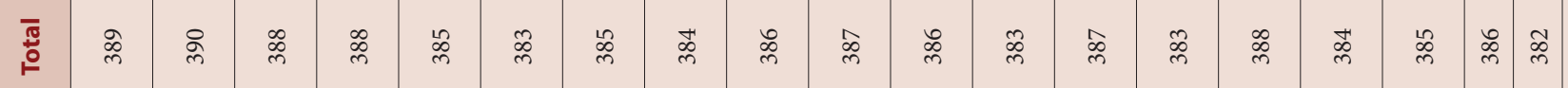

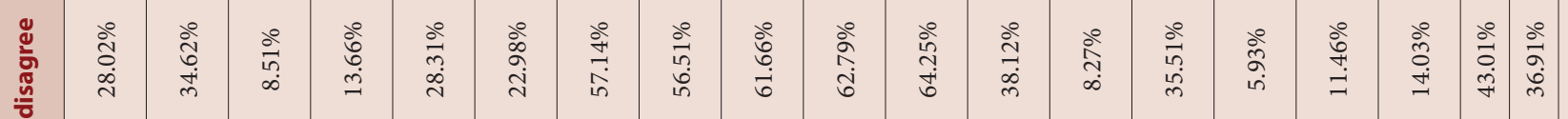

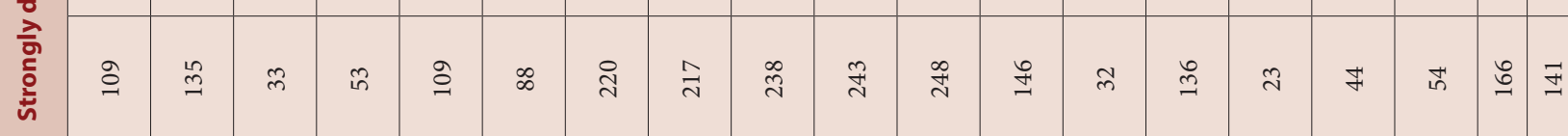

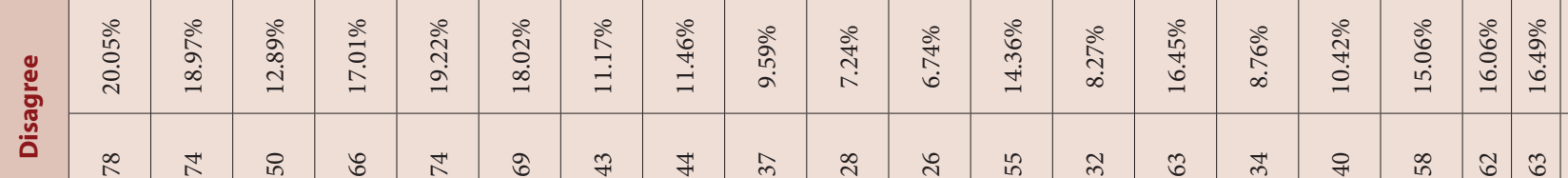

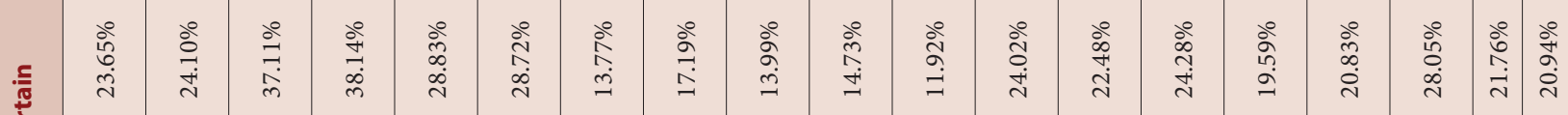

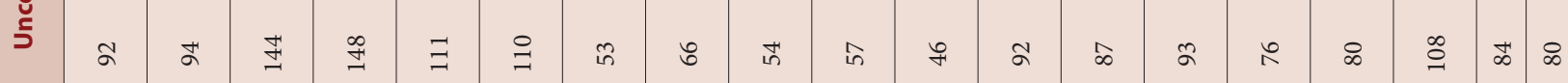

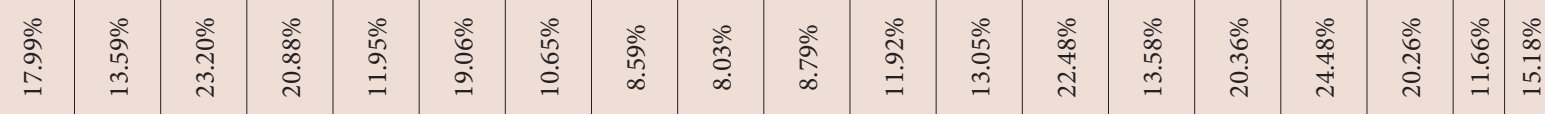

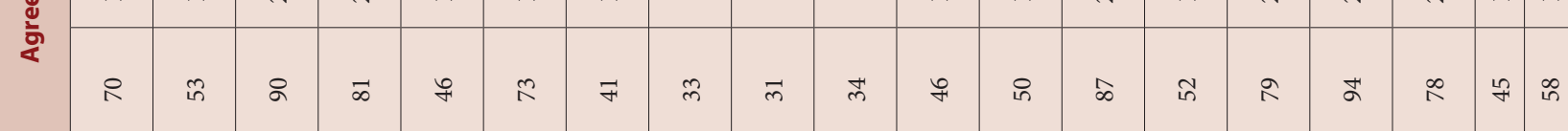

\begin{tabular}{|c|c|c|c|c|c|c|c|c|c|c|c|c|c|c|c|c|c|c|c|c|c|}
\hline \multirow[b]{2}{*}{ 节 } & 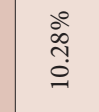 & 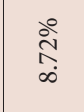 & 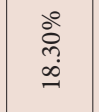 & $\frac{\stackrel{\circ}{m}}{\stackrel{0}{0}}$ & $\begin{array}{l}\text { ذे } \\
\stackrel{0}{=}\end{array}$ & 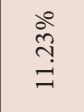 & רָ̀ & ìं & 六 & कृष & $\stackrel{\infty}{\stackrel{0}{\circ}}$ & 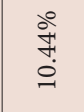 & $\begin{array}{l}\text { Dे } \\
\text { ch } \\
\infty \\
\infty \\
\infty\end{array}$ & $\begin{array}{l}\stackrel{0}{\infty} \\
\stackrel{0}{0}\end{array}$ & $\begin{array}{l}\text { ठें } \\
\stackrel{2}{1} \\
\stackrel{f}{f}\end{array}$ & 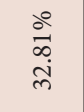 & $\begin{array}{l}\text { ठे } \\
\text { ¿े } \\
\text { i }\end{array}$ & 产 & 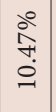 & & \\
\hline & q & హ゙ & ה & q & f & $\stackrel{?}{F}$ & $\stackrel{\infty}{\sim}$ & $\underset{\sim}{\sim}$ & 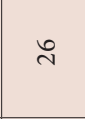 & $\stackrel{2}{\wedge}$ & ㄱ & 아 & से & ले & 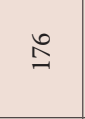 & 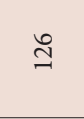 & $\infty$ & iे & q & & \\
\hline & 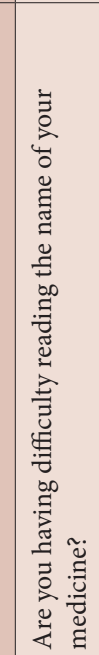 & 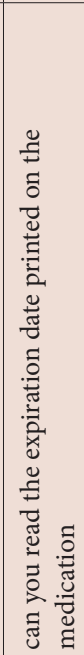 & 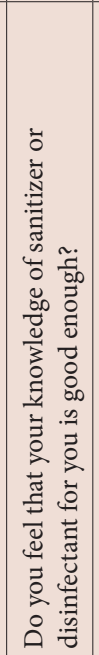 & 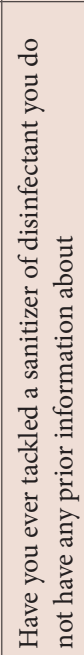 & 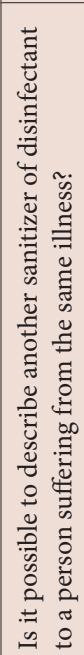 & 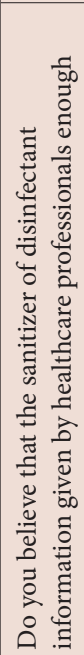 & 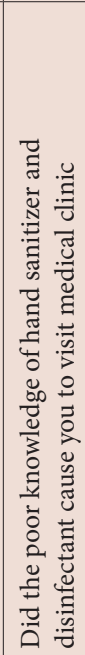 & 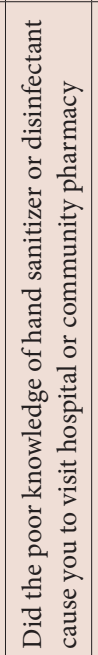 & 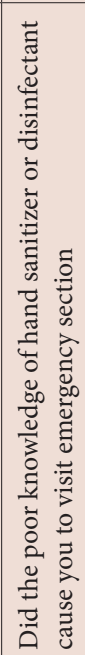 & 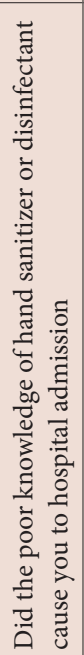 & 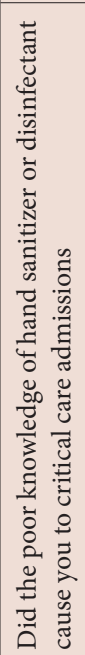 & 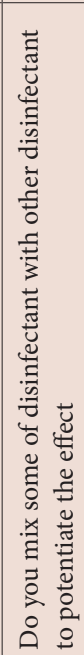 & 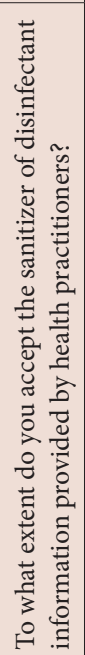 & 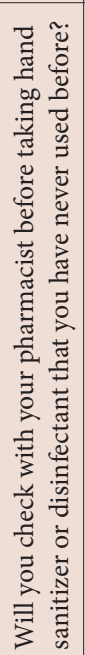 & 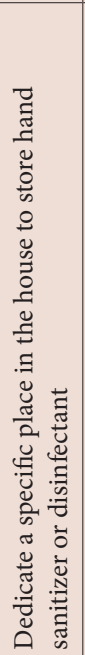 & 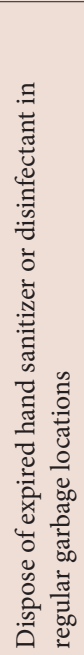 & 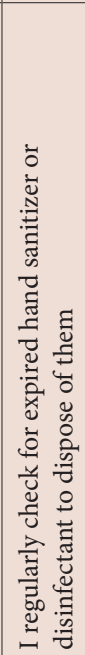 & 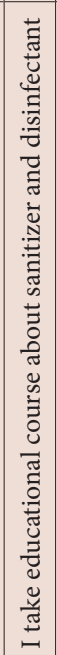 & 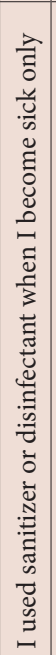 & 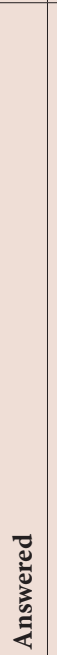 & \\
\hline
\end{tabular}


Table 4: Perception of patients towards the use of hand sanitizer and disinfectants Saudi Arabia.

\begin{tabular}{|c|c|c|c|c|c|c|c|c|c|c|c|c|c|}
\hline \multirow[b]{2}{*}{$\begin{array}{l}\text { There is a difference between } \\
\text { healthcare professionals about } \\
\text { sanitizer and disinfectant information } \\
\text { provided to patients }\end{array}$} & \multicolumn{2}{|c|}{$\begin{array}{l}\text { Strongly } \\
\text { agree }\end{array}$} & \multicolumn{2}{|c|}{ Agree } & \multicolumn{2}{|c|}{ Uncertain } & \multicolumn{2}{|c|}{ Disagree } & \multicolumn{2}{|c|}{$\begin{array}{l}\text { Strongly } \\
\text { disagree }\end{array}$} & \multirow{2}{*}{$\begin{array}{c}\text { Total } \\
385\end{array}$} & \multirow{2}{*}{$\begin{array}{c}\text { Weighted } \\
\text { Average }\end{array}$} & \multirow{2}{*}{$\begin{array}{c}p \text {-value } \\
0.000\end{array}$} \\
\hline & $15.58 \%$ & 60 & $26.23 \%$ & 101 & $39.48 \%$ & 152 & $13.51 \%$ & 52 & $5.19 \%$ & 20 & & & \\
\hline $\begin{array}{l}\text { Some pharmacists prescribe expensive } \\
\text { medicines and some prescribe cheap }\end{array}$ & $14.51 \%$ & 56 & $27.20 \%$ & 105 & $41.45 \%$ & 160 & $10.62 \%$ & 41 & $6.22 \%$ & 24 & 386 & 3.33 & 0.000 \\
\hline $\begin{array}{l}\text { The pharmacists provide very useful } \\
\text { information about sanitizer and } \\
\text { disinfectant }\end{array}$ & $17.31 \%$ & 67 & $31.27 \%$ & 121 & $37.21 \%$ & 144 & $10.08 \%$ & 39 & $4.13 \%$ & 16 & 387 & 3.48 & 0.000 \\
\hline $\begin{array}{l}\text { I benefit more from the information } \\
\text { the pharmacist provides about } \\
\text { sanitizer and disinfectant than } \\
\text { physicians }\end{array}$ & $14.77 \%$ & 57 & $27.72 \%$ & 107 & $41.45 \%$ & 160 & $11.40 \%$ & 44 & $4.66 \%$ & 18 & 386 & 3.37 & 0.000 \\
\hline $\begin{array}{l}\text { Often there is coordination between } \\
\text { physicians and the pharmacies } \\
\text { neighboring them in sanitizer and } \\
\text { disinfectant }\end{array}$ & $9.33 \%$ & 36 & $31.87 \%$ & 123 & $39.64 \%$ & 153 & $14.77 \%$ & 57 & $4.40 \%$ & 17 & 386 & 3.27 & 0.000 \\
\hline $\begin{array}{l}\text { I think there is no great benefit from } \\
\text { sanitizer and disinfectant }\end{array}$ & $5.70 \%$ & 22 & $11.14 \%$ & 43 & $26.17 \%$ & 101 & $31.61 \%$ & 122 & $25.39 \%$ & 98 & 386 & 2.40 & 0.000 \\
\hline $\begin{array}{l}\text { Herbal medicines used as sanitizers } \\
\text { and disinfectant are much better than } \\
\text { regular sanitizer and disinfectant }\end{array}$ & $5.45 \%$ & 21 & $13.25 \%$ & 51 & $30.91 \%$ & 119 & $30.39 \%$ & 117 & $20.00 \%$ & 77 & 385 & 2.54 & 0.000 \\
\hline $\begin{array}{l}\text { Medicines for oral and dental } \\
\text { treatment not covered by medical } \\
\text { insurance }\end{array}$ & $13.58 \%$ & 52 & $21.67 \%$ & 83 & $51.44 \%$ & 197 & $8.62 \%$ & 33 & $4.70 \%$ & 18 & 383 & 3.31 & 0.000 \\
\hline $\begin{array}{l}\text { Ssanitizer and disinfectant do not } \\
\text { conflict with other medicines, such as } \\
\text { heart disease or diabetes }\end{array}$ & $7.01 \%$ & 27 & $16.10 \%$ & 62 & $51.69 \%$ & 199 & $16.88 \%$ & 65 & $8.31 \%$ & 32 & 385 & 2.97 & 0.000 \\
\hline $\begin{array}{l}\text { There are no side effects for sanitizer } \\
\text { and disinfectant }\end{array}$ & $7.29 \%$ & 28 & $14.84 \%$ & 57 & $32.29 \%$ & 124 & $31.77 \%$ & 122 & $13.80 \%$ & 53 & 384 & 2.70 & 0.000 \\
\hline $\begin{array}{l}\text { The over usage of sanitizer and } \\
\text { disinfectant cause us a lot of accidents }\end{array}$ & $9.07 \%$ & 35 & $30.83 \%$ & 119 & $29.02 \%$ & 112 & $22.28 \%$ & 86 & $8.81 \%$ & 34 & 386 & 3.09 & 0.000 \\
\hline $\begin{array}{l}\text { here is a big difference between } \\
\text { sanitizer and disinfectant in efficacy } \\
\text { and safety }\end{array}$ & $24.74 \%$ & 95 & $36.98 \%$ & 142 & $29.43 \%$ & 113 & $5.99 \%$ & 23 & $2.86 \%$ & 11 & 384 & 3.75 & 0.000 \\
\hline $\begin{array}{l}\text { The prices of sanitizer and disinfectant } \\
\text { is the best factor to get them }\end{array}$ & $9.79 \%$ & 38 & $24.74 \%$ & 96 & $30.67 \%$ & 119 & $28.09 \%$ & 109 & $6.70 \%$ & 26 & 388 & 3.03 & 0.000 \\
\hline $\begin{array}{l}\text { The efficacy and safety of sanitizer } \\
\text { and disinfectant is the best factor to } \\
\text { get them }\end{array}$ & $37.56 \%$ & 145 & $35.75 \%$ & 138 & $19.17 \%$ & 74 & $4.92 \%$ & 19 & $2.59 \%$ & 10 & 386 & 4.01 & 0.000 \\
\hline $\begin{array}{l}\text { You can find The sanitizer and } \\
\text { disinfectant at most places at my } \\
\text { house }\end{array}$ & $21.45 \%$ & 83 & $31.27 \%$ & 121 & $27.39 \%$ & 106 & $16.54 \%$ & 64 & $3.36 \%$ & 13 & 387 & 3.51 & 0.000 \\
\hline $\begin{array}{l}\text { I prefer to use the sanitizer and } \\
\text { disinfectant more than water and soap }\end{array}$ & $11.14 \%$ & 43 & $18.13 \%$ & 70 & $29.02 \%$ & 112 & $29.79 \%$ & 115 & $11.92 \%$ & 46 & 386 & 2.87 & 0.000 \\
\hline Answered & & & & & & & & & & & 389 & & \\
\hline Skipped & & & & & & & & & & & 13 & & \\
\hline
\end{tabular}




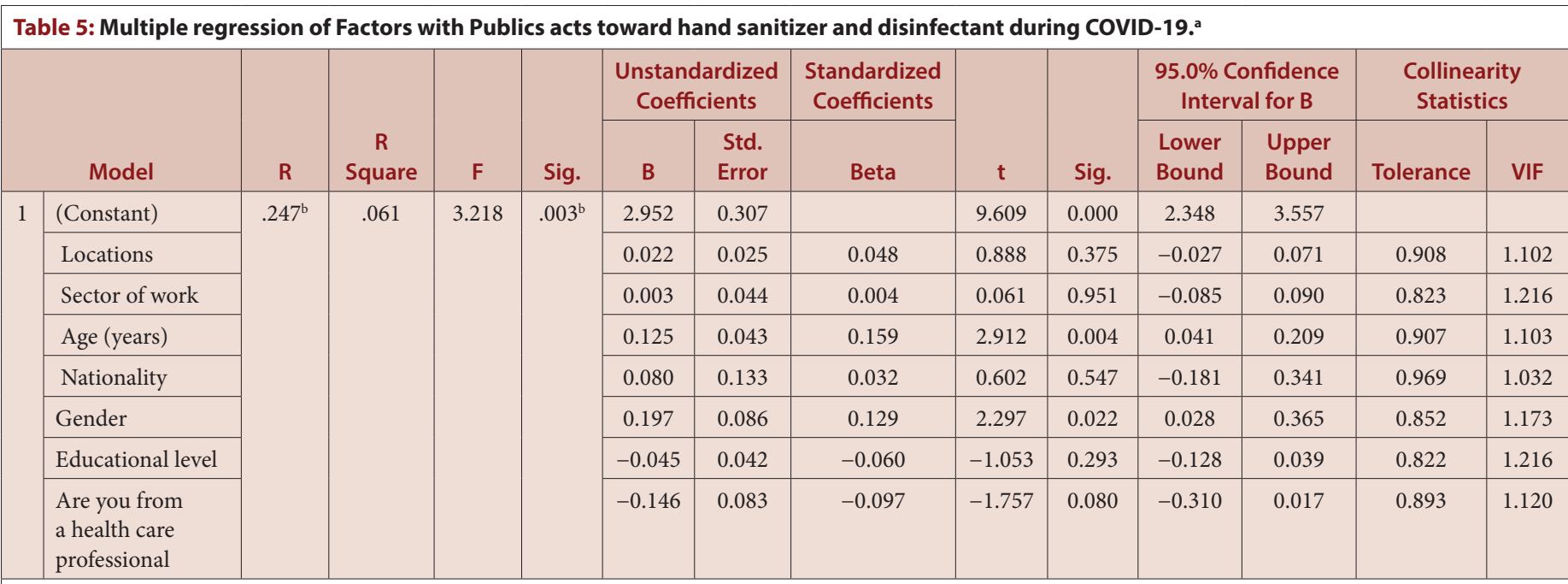

a. Dependent Variable: the Publics acts toward hand sanitizer and disinfectant during convid-19a , Predictors: (Constant), Location, Site of work, Age, Nationality, Gender, Educational level, Are you from the health care professional (Medical Doctor- Dentist- Pharmacist- Nurse- Others),

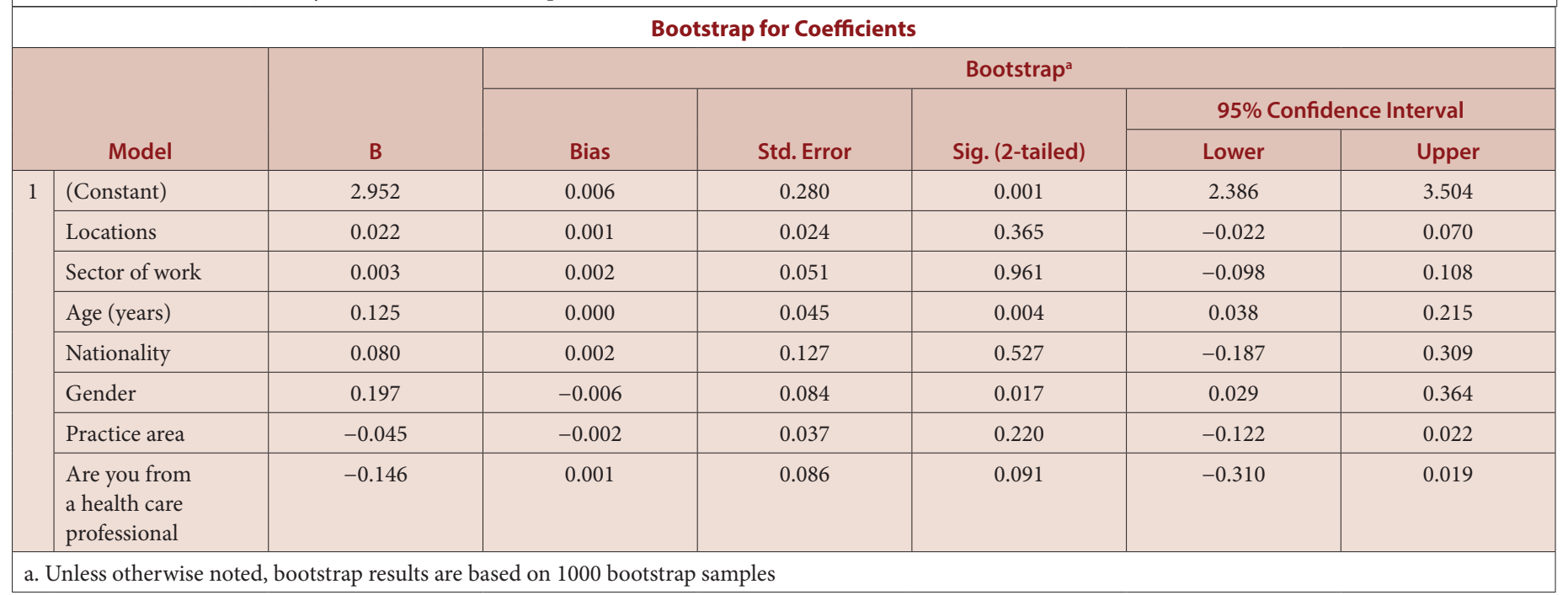

and disinfectant" received the highest responses. That shows that the perception is good, but misunderstanding usage in the practice because the patients could not differentiate among sanitizer and disinfectant types. The national and international registration agencies should emphasize the public perception during sanitizer and disinfectant registration with public education and awareness sessions. According to our results, the responders thought there was a big difference in safety and efficacy between generic sanitizer and disinfectant brands. Moreover, the misuse of sanitizer and disinfectants in terms of indication, use, and frequency of usage might cause negative perceptions. The responders might have these problems in practice, emphasizing awareness of the sanitizer and disinfectant. Most disinfectants are not required to be officially registered by the registration body or through the Ministry of Trade. The responders agreed that the sanitizer and disinfectant should be stored in appropriate places in the house to prevent any child accidents. The majority of responders believed that the sanitizer or disinfectant is effective in disease prevention and transmission, which led them to use the disinfectants properly. The responders agreed that chemical-based sanitizers and disinfectants were better than those made of herbal origin, which leads to appropriate usage prevents misuse of herbal medications. The responders disagreed that there are no side effects to the use of sanitizers and disinfectants, which is expected because the responders deal with sanitizers and disinfectants as regular medications with a positive attitude and perception.

Various factors affected the attitude and perception of using sanitizer and disinfectant during COVID-19. However, only two factors (i.e., nationality and occupational status) did not affect the attitude and perception toward sanitizer and disinfectant. The location also affected the attitude toward sanitizer and disinfectant. For example, the responders from the western region had a positive attitude toward sanitizer and disinfectant use, which might be related to the increased awareness compared to other regions. Males showed a positive attitude toward sanitizer and disinfectant use than females. Young age and low academic qualifications showed a lower attitude toward sanitizer and disinfectant use due to insufficient knowledge of their importance during the COVID-19 pandemic. In addition, the healthcare providers showed a positive attitude toward sanitizer and disinfectant use than that of non-healthcare professionals, which is expected because of their knowledge and practice. The age and gender factors had dependent on the positive increase of perception toward the sanitizer and disinfectant. If those factors existed, the perceptions increased by $12-15 \%$. Thus, no factors affect public perception of using sanitizers and disinfectants, 


\begin{tabular}{|c|c|c|c|c|c|c|c|c|c|c|c|}
\hline \multirow[b]{2}{*}{$\begin{array}{c}\mathbf{R} \\
\text { Square } \\
\end{array}$} & \multirow[b]{2}{*}{$F$} & \multirow[b]{2}{*}{ Sig. } & \multicolumn{2}{|c|}{$\begin{array}{l}\text { Unstandardized } \\
\text { Coefficients }\end{array}$} & \multirow{2}{*}{$\begin{array}{c}\begin{array}{c}\text { Standardized } \\
\text { Coefficients }\end{array} \\
\text { Beta } \\
\end{array}$} & \multirow[b]{2}{*}{$t$} & \multirow[b]{2}{*}{ Sig. } & \multicolumn{2}{|c|}{$\begin{array}{l}95.0 \% \text { Confidence } \\
\text { Interval for B }\end{array}$} & \multicolumn{2}{|c|}{$\begin{array}{l}\text { Collinearity } \\
\text { Statistics }\end{array}$} \\
\hline & & & B & $\begin{array}{l}\text { Std. } \\
\text { Error }\end{array}$ & & & & $\begin{array}{l}\text { Lower } \\
\text { Bound }\end{array}$ & $\begin{array}{l}\text { Upper } \\
\text { Bound }\end{array}$ & Tolerance & VIF \\
\hline \multirow[t]{7}{*}{.023} & \multirow[t]{7}{*}{1.177} & \multirow[t]{7}{*}{$.315^{\mathrm{b}}$} & 2.731 & 0.222 & & 12.325 & 0.000 & 2.295 & 3.167 & & \\
\hline & & & 0.025 & 0.018 & 0.077 & 1.385 & 0.167 & -0.010 & 0.060 & 0.911 & 1.098 \\
\hline & & & 0.068 & 0.031 & 0.124 & 2.216 & 0.027 & 0.008 & 0.129 & 0.905 & 1.105 \\
\hline & & & -0.098 & 0.097 & -0.055 & -1.014 & 0.311 & -0.289 & 0.092 & 0.968 & 1.033 \\
\hline & & & -0.016 & 0.062 & -0.015 & -0.253 & 0.801 & -0.137 & 0.106 & 0.854 & 1.171 \\
\hline & & & -0.010 & 0.031 & -0.020 & -0.341 & 0.734 & -0.070 & 0.050 & 0.824 & 1.214 \\
\hline & & & -0.001 & 0.060 & -0.001 & -0.021 & 0.983 & -0.119 & 0.117 & 0.894 & 1.119 \\
\hline
\end{tabular}

a. Dependent Variable: the perception of public towards the use of hand sanitizer and disinfectants during COVID-19', Predictors: (Constant), Location, Site of work, Age, Nationality, Gender, Educational level, Are you from the health care professional (Medical Doctor- Dentist- Pharmacist- Nurse- Others),

\begin{tabular}{|c|c|c|c|c|c|c|c|}
\hline \multicolumn{8}{|c|}{ Bootstrap for Coefficients } \\
\hline \multirow{2}{*}{\multicolumn{2}{|c|}{ Model }} & \multirow{2}{*}{ B } & \multicolumn{5}{|c|}{ Bootstrap ${ }^{a}$} \\
\hline & & & Bias & Std. Error & Sig. (2-tailed) & \multicolumn{2}{|c|}{ 95\% Confidence Interval } \\
\hline \multirow[t]{6}{*}{1} & (Constant) & 2.731 & -0.010 & 0.215 & 0.001 & 2.298 & 3.136 \\
\hline & Locations & 0.025 & 0.001 & 0.018 & 0.159 & -0.008 & 0.061 \\
\hline & Nationality & -0.098 & 0.001 & 0.090 & 0.279 & -0.280 & 0.075 \\
\hline & Gender & -0.016 & $-9.236 \mathrm{E}-05$ & 0.064 & 0.820 & -0.141 & 0.105 \\
\hline & Practice area & -0.010 & 0.000 & 0.029 & 0.715 & -0.070 & 0.046 \\
\hline & $\begin{array}{l}\text { Are you from } \\
\text { a health care } \\
\text { professional }\end{array}$ & -0.001 & 0.002 & 0.057 & 0.976 & -0.119 & 0.112 \\
\hline
\end{tabular}

including positive or negative attitudes. However, a single factor (age) was a dependent factor toward a positive direction. If the age increases, the positive perception will increase by $12 \%$ because of maturity and more knowledge than young age.

\section{Limitation}

The results of this study provided a lot of information about the public's perception of sanitizer and disinfectants. Expert reviewers validated the results with a high-reliability survey. In addition, the study had an appropriate sample size. However, there were limitations such as different ages, educational levels, occupational status, and an unequal number of membership of healthcare professionals. Moreover, there were only a few studies about public knowledge of sanitizer and disinfectants for comparing results. Therefore, further studies with comparable demographic data are suggested to overcome the limitations mentioned above.

\section{CONCLUSION}

In conclusion, the level of perception of the public about sanitizer and disinfectants was insufficient in the Kingdom of Saudi Arabia. The public obtained appropriate scientific information about sanitizers and disinfectants from healthcare professionals. They agreed with the proper storage of sanitizer and disinfectant. On the contrary, the perception of the benefits of sanitizer and disinfectant and contraindications related to their use was insufficient. The majority of the factors did not affect the perception of the public about sanitizers and disinfectants. However, age plays an essential role in a positive change of perception. Therefore, a comprehensive campaign of education and training to the public about sanitizer and disinfectants is highly recommended ${ }^{31}$ to improve the perception, knowledge, and utilization of sanitizers and disinfectants.

\section{ACKNOWLEDGEMENT}

None.

\section{CONFLICT OF INTEREST}

The authors declare that there is no conflict of interest.

\section{Funding}

None

\section{Consent for Publications}

Informed consent was obtained from all the participants 


\section{Ethical Approval}

This research is exempted from research and ethical committee or an institutional review board (IRB) approval.

https://www.hhs.gov/ohrp/regulations-and-policy/decisioncharts-2018/index.html

\section{ABBREVIATIONS}

COVID-19: Coronavirus; MOH: Ministry of Health; KSA: Kingdom of Saudi Arabia; SPSS: Statistical package of social sciences; JASP: Jeffery's Amazing Statistics Program; STROBE: Strengthening the reporting of observational studies epidemiology.

\section{ORCID ID}

Yousef Ahmed Alomi (D) https://orcid.org/0000-0003-1381-628X

\section{REFERENCES}

1. Al-Sayah MH. Chemical disinfectants of COVID-19: An overview. J Water Health. 2020;18(5):843-8. doi: 10.2166/wh.2020.108, PMID 33095205.

2. Rutala WA, Weber DJ. Disinfection, sterilization, and control of hospital waste. In: Mandell, Douglas, editors, and Bennett's Principles and Practice of Infectious Diseases; 2014. p. 3294-3309.e1.

3. Rutala WA, Weber DJ, Weinstein RA, Pearson ML. Guideline for disinfection and sterilization in healthcare facilities; 2008. Miscellaneous inactivating agents [internet]. CDC [website. p. 2019]. Available from: http://www.cdc.gov/hicpac/ Disinfection_Sterilization/10_0MiscAgents.html [cited 22/11/2021].

4. Song $X$, Vossebein L, Zille A. Efficacy of disinfectant-impregnated wipes used for surface disinfection in hospitals: A review. Antimicrob Resist Infect Control. 2019;8:139. doi: 10.1186/s13756-019-0595-2, PMID 31452873.

5. US Department of Health and Human Services, Centers for Disease Contro and Prevention. Infection control in healthcare personnel: infrastructure and routine practices for occupational infection prevention and control services recommendations only. p. 1-8; 2019. Available from: https://www.cdc.gov/ infectioncontrol/pdf/guidelines/infection-control-HCP-recommendations-only-H. pdf [cited 22/11/2021]

6. Rutala WA, Weber DJ. Disinfection and sterilization in health care facilities: What clinicians need to know. Clin Infect Dis. 2004;39(5):702-9. doi: 10.1086/423182 PMID 15356786.

7. Sessa A, Di Giuseppe G, Albano L, Angelillo IF, Collaborative Working Group. An investigation of nurses' knowledge, attitudes, and practices regarding disinfection procedures in Italy. BMC Infect Dis. 2011 May 25;11:148. doi: 10.1186/1471-2334-11-148, PMID 21612613

8. Stutz N, Becker D, Jappe U, John SM, Ladwig A, Spornraft-Ragaller P, et al. Nurses' perceptions of the benefits and adverse effects of hand disinfection: alcohol-based hand rubs vs. hygienic handwashing: A multicentre questionnaire study with additional patch testing by the German Contact Dermatitis Research Group. Br J Dermatol. 2009 Mar;160(3):565-72. doi: 10.1111/j.13652133.2008.08951.x, PMID 19067700.

9. Peres D, Severo M, Ferreira MA. Knowledge, source of information, and perception of Portuguese medical students and junior doctors of infection control precautions. Am J Infect Control. 2016;44(12):1723-5. doi: 10.1016/j. ajic.2016.05.018, PMID 27499194

10. Khubrani A, Albesher M, Alkahtani A, Alamri F, Alshamrani M, Masuadi E. Knowledge and information sources on standard precautions and infection control of health sciences students at King Saud Bin Abdulaziz University for Health Sciences, Saudi Arabia, Riyadh. J Infect Public Health. 2018 Jul 1;11(4):546-9. doi: 10.1016/j.jiph.2017.10.013, PMID 29137958.

11. Murtough SM, Hiom SJ, Palmer M, Russell AD. A survey of rotational use of biocides in hospital pharmacy aseptic units. J Hosp Infect. 2002;50(3):228-31. doi: 10.1053/jhin.2001.1155, PMID 11886201
12. Sum ZZ, Ow CJW. Community pharmacy response to infection control during COVID-19. A cross-sectional survey. Res Social Adm Pharm. 2021;17(1):1845-52. doi: 10.1016/j.sapharm.2020.06.014, PMID 33317763.

13. Adegboye MB, Zakari S, Ahmed BA, Olufemi GH. Knowledge, awareness and practice of infection control by health care workers in the intensive care units of a tertiary hospital in Nigeria. Afr Health Sci. 2018 Mar 1:18(1):72-8. doi: 10.4314/ ahs.v18i1.11, PMID 29977260

14. Gharpure $R$, Hunter $C M$, Schnall $A H$, Barrett CE, Kirby AE, Kunz J, et al. Garcia-Williams AG Knowledge and Practices Regarding Safe Household Cleaning and Disinfection for COVID-19 Prevention - United States, May 2020. MMWR Morb Mortal Wkly Rep. 2020;69(23):705-9. doi: 10.15585/mmwr. mm6923e2. PMID 32525852

15. Charan J, Biswas T. How to calculate sample size for different study designs in medical research? Indian J Psychol Med. 2013;35(2):121-6. doi: 10.4103/02537176.116232, PMID 24049221.

16. Pourhoseingholi MA, Vahedi M, Rahimzadeh M. Sample size calculation in medical studies. Gastroenterol Hepatol Bed Bench. 2013;6(1):14-7. PMID 24834239.

17. Ezhumalai DG. How Big A Sample Do I Require?. Annals of SBV. 2017;6(1):39-41. doi: 10.5005/jp-journals-10085-6113.

18. Johnson TP, Wislar JS. Response rates and nonresponse errors in surveys [internet]. JAMA. 2012;307(17):1805-6. doi: 10.1001/jama.2012.3532, PMID 22550194

19. Von Elm E, Altman DG, Egger M, Pocock SJ, Gøtzsche PC, Vandenbroucke JP. The strengthening the reporting of observational studies in epidemiology (STROBE) statement: Guidelines for reporting observational studies. PLOS Med. 2007;4(10):1623-7. doi: 10.1371/journal.pmed.0040296.

20. Von Elm E, Altman DG, Egger M, Pocock SJ, Gøtzsche PC, Vandenbroucke JP The Strengthening the Reporting of Observational Studies in Epidemiology (STROBE) statement: Guidelines for reporting observational studies [internet]. Vol. 370; 2007. Available from: http://www.thelancet.com. Available from: http:// www.plosmedicine.org [cited 22/11/2021].

21. Langan SM, Schmidt SA, Wing K, Ehrenstein V, Nicholls SG, Filion KB, et al. The reporting of studies conducted using observational routinely collected health data statement for pharmacoepidemiology (RECORD-PE). BMJ. 2018;363:k3532. doi: 10.1136/bmj.k3532, PMID 30429167

22. Liao D, Valliant R. Variance inflation factors in the analysis of complex survey data. Surv Methodol. 2012;38(1):53-62.

23. Akinwande MO, Dikko HG, Samson A. Variance inflation factor: as a condition for the inclusion of suppressor variable(s) in regression analysis. Open J Stat. 2015;05(7):754-67. doi: 10.4236/ojs.2015.57075.

24. Thompson CG, Kim RS, Aloe AM, Becker BJ. Extracting the Variance Inflation Factor and Other Multicollinearity Diagnostics from Typical Regression Results. Basic Appl Soc Psych. 2017;39(2):81-90. doi: 10.1080/01973533.2016.1277529.

25. Algaissi AA, Alharbi NK, Hassanain M, Hashem AM. Preparedness and response to COVID-19 in Saudi Arabia: Building on MERS experience. J Infect Public Health. 2020;13(6):834-8. doi: 10.1016/j.jiph.2020.04.016, PMID 32451260

26. Alomi YA, Al-Jarallah SM. Role of Pharmacist in the epidemic, pandemic, and emergency public health with an emphasis on coronavirus Disease (COVID-19). IJPCS. 2021;10(1):1-5. doi: 10.5530/ijpcs.2021.10.1.

27. Varghese GM, John $R$, Manesh $A$, Karthik $R$, Abraham OC. Clinical management of COVID-19. Indian J Med Res. 2020;151(5):401-10. doi: 10.4103/ijmr. IJMR 957_20, PMID 32611911.

28. Multidisciplinary management guidelines of Covid-19

29. Gerster FM, Vernez D, Wild PP, Hopf NB. Hazardous substances infrequently used professional cleaning products. Int J Occup Environ Health. 2014;20(1):46-60 doi: 10.1179/2049396713Y.0000000052, PMID 24804339

30. Glegg GA, Richards JP. Chemicals in household products: problems with solutions. Environ Manage. 2007;40(6):889-901. doi: 10.1007/s00267-007-9022-1 PMID 17902015

31. Octavia DR, Nurafifah D, Utami PR, Pangestu DP. The Effect of Counseling and Training on Public Knowledge about Making Hand sanitizer from Betel Extract. J Asian Multicult Res Med Heal Sci Study. 2021;2(2):8-16. 